\title{
Computing without sociology and history is useless.
}

\author{
Camille Akmut
}

February 17, 2020

\begin{abstract}
Retrograde ACM / Skip, Baldwin and the cops / Being rich is not easy / The weird crowd up in Cambridge (academic hustling on Vassar St and by Harvard Sq, fluffy hats, cute nicknames, dislike of capitalization, ...) / etc.

[Notes and essays written around the time of my studies on diversity.]
\end{abstract}


"Moreover, one would be mistaken in thinking that quantitative knowledge was free of the perils of qualitative knowledge. Quantity is not automatically a measure of objectivity..." (Gaston Bachelard, The formation of the scientific spirit - trans.)

"Until the Russian Revolution, Karl Marx was little known in America. He was treated condescendingly in the universities, and regarded even by the intelligent public as a radical agitator whose curious and inconvenient theories it was easy to refute. Today, at last, we all know better, and we see in Karl Marx a colossal genius of infinite sacrifice and monumental industry" (W.E.B. Du Bois, Marxism and the negro problem)

"Let's not pay rent and see what happens." ( Megg)

"[East St. Louis, IL 1917] there occurred one of the many "race riots" that took place in what our white-oriented history books called the "Progressive Era." (...) white workers, angered by the influx of black workers, killed perhaps 200 people, provoking (...) Josephine Baker to say: "The very idea of America makes me shake and tremble and gives me nightmares."" 


\section{Being a millionaire is difficult / On social history}

The history of Hillary Clinton - contrary to claims made by herself in the context of a recent appearance on the Ellen Degeneres show (both multimillionaires) - is no more that of American women in the 20th and 21st century, than the history of Rockefeller or Vanderbilt women and their daughters was that of American women in the 19th; no more than the life of Marie Antoinette was that of her maidservants, or of female laborers in the 18th; no more than the concerns of the kings and queens of England were those of the working class, men and women, during those same periods (except and only in some negative, inverted fashion).

History, in particular social history, is one of the few weapons that we have at our disposal to defend ourselves.

In Howard Zinn's A people's history, women, in particular working-class women, are always put on the front stage :

"In Lawrence, Massachusetts, in 1860, on a winter day, the Pemberton Mill collapsed, with nine hundred workers inside, mostly women"

- the reader can read among many other stories in this great book (ch. 10).

But, the system described by Zinn, in which such events could occur, which is to say death brought on by capitalistic greed in the 19th c. (an engineer knew about construction flaws, and a jury acquitted the company), remains ours :

"a system which [is] chaotic in its nature, in which only the very rich [are] secure (...) [brings] cold, hunger, and death to working people while the fortunes of the Astors, Vanderbilts, Rockefellers, Morgans, [keep] growing through war and peace, crisis and recovery";

a system in which the poor must give up on even their most cherished ideals and dreams, in an attempt to survive, while the rich pass theirs as universal.

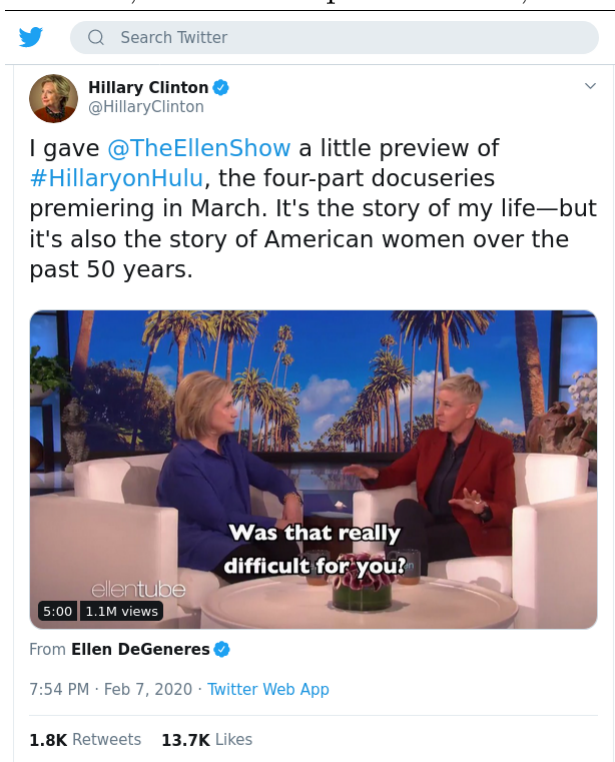




\section{Private colleges, private interests : recent and older history from Harvard, MIT et al}

\section{Harvard, the 1912 "Bread and Roses" workers' strike, and beyond}

" "Defend Your Class" [was a] slogan that Harvard deployed to inspire its students to leave the classroom in 1912 and take up arms with the National Guard to break the Lawrence "Bread and Roses" textile workers' strike (...) a movement of the working class, men, women, and children, of thirty countries of origin (...) demanding freedom from the daily threats to their lives posed by underpaid and dangerous jobs (...) the Harvard students received course credit.

This institution stands shoulder to shoulder with the National Guard of 1912, the Henry Kissingers of 1969, and the war-mongering presidents of the $2000 \mathrm{~s}$

The (...) impulses of this institution are not random; they are not unrelated. Harvard is a case study in the unified power of the elite"

(Source : 'Harvard's Progress Is Not Our Progress', Jacobin. 15/02/20. See also ch. 13 of Zinn's "A people's history", for the 1912 strike.)

Kissinger and Bush Jr. both attended Harvard, where they either learned much, or little from their " "political" science" and business/economics professors; in both cases a failure of this institution.

From early 20th c. labor busting for course credits, to early 21st c. wars for oil profits : it was a difference in degrees - not in nature - that took these Harvard students from here to there...

\section{High technology, same ethos : MIT's "Media Lab" and Harvard's "Berkman Klein Center"}

Harvard's "Berkman Klein Center" is more or less the equivalent of MIT's "Media Lab".

Overlap in personnel - e.g. D. B. - and orientations, etc.;

Parallels which The Intercept article on the topic failed to explore, limiting itself to note merely that both institutions participated in the same "ethics in Al" (pseudo-)research.

The court ruling that I used in "A recent precedent on cy pres practices" however did explicitly name the Berkman center as entertaining questionable proximity with businesses. Similar such 
"Media lab"'s and "Center"'s exist at various other universities of similar profiles...

III. Further context : funding of public and private higher education in Boston

\begin{tabular}{|l|l|}
\hline Institution & Endowment \\
\hline Harvard & $\$ 40.9$ billion \\
\hline MIT & $\$ 17.5$ billion \\
\hline Boston College & $\$ 2.5$ billion \\
\hline Boston University & $\$ 2.3$ billion \\
\hline Tufts & $\$ 1.8$ billion \\
\hline Brandeis & $\$ 1$ billion \\
\hline Northeastern University & $\$ 1$ billion \\
\hline
\end{tabular}

Table : endowment of Boston's private and public colleges, universities (current estimate) UMass Boston's endowment, "the only public university in Boston"? \$78 million. (Source : aggregated Wikipedia data.) 


\section{Things that I will (also) need}

- ACM, not the most progressive institution ever... Opposed open access, specifically :

"opposition to proposed administration policy" on "the immediate free distribution of peer-reviewed journal articles"

https://newsroom. publishers.org/researchers-and-publishers-oppose-immediate-free-distributionof-peer-reviewed-journal-articles/ (18/12/19)

(They signed along notoriously conservative - and downright felonious - institutions like the APA. Note also the presence of the $U$. of Chicago Press...)

When their signature of this letter was made public, many complaints ensued : ACM "on the wrong side of this issue"!

https://nitter.net/ACM_president/status/1208075804854218752 (20/12/19)

This however did not deter them, and they pretty much just made up excuses :

"we support other publishers in protesting [this] regulatory change", "there wasn't time", etc..

This got people even more angry.

Then they finally flip-flopped :

They got so scared in fact (people were threatening to end their memberships = no money) that they published a response back to back in 'ACM Bulletins', and 'ACM News' the next day :

https://www.acm.org/articles/bulletins/2020/january/message-from-the-acm-president-regardingopen-access (07/01/20) https://cacm.acm.org/news/242011-message-from-the-acm-president-regarding-openaccess/fulltext (08/01/20)

"Over the past few weeks, ACM leadership has listened to the concerns of our members..." yadayada

- More

In the presentation, after the GNU Project I will also present from my research on diversity and the Linux kernel. 
That way I will have covered the two biggest free software projects today (or "GNU + Linux", literally).

(I will try to do cover one additional, small(er) project, but I'm undecided and not sure if I can do it untilthen.)

Data from an additional project will be presented : OTRv4 (whose implementation, ie. otr4, is licensed under the GPLv3, and done by about the same people who are involved in the specification.)

- Clarence Ellis quote (full)

"It was obvious to any unbiased observer that the kid born in May, 1943, should be a mathematician within the Academy. However, there were no unbiased observers; the kid was Black, and born in the Chicago ghetto. (...)

My almost-all-Black high school in my almost-all-Black neighborhood of Chicago was woefully inadequate preparation for my college studies. Much of my scholastic time in various colleges and universities was catching up with the knowledge and techniques of others. This was arduous and difficult work requiring strong persistence. My first years at college were indeed tough and lonely times;"

“Affective computing”, ch. 12 'Making it on broken promises' (2002)

Clarence Ellis : first African American to obtain a Ph.D. in computer science, in 1969 (per this autobiography, also) from Uol

One of the 4 black computer scientists mentioned in the 2003 JBHE study is actually Clarence Ellis.

- James Baldwin quote

[Since I recommended James Baldwin as further reading, I don't intend to leave this as merely an empty reference.]

"When I was ten, ... two policemen amused themselves with me by frisking me, making comic (and terrifying) speculations concerning my ancestry and [sexuality], and ... leaving me flat on my back in one of Harlem's empty lots“"

“"The problem of the twentieth century," wrote W. E. B. Du Bois around sixty years ago, "is the problem of the colour line." A fearful and delicate problem, which compromises ... all the American efforts to build a better world - here, there, or anywhere." 
It is "we ... the relatively conscious whites and the relatively conscious blacks, who must, like lovers, insist on, or create, the consciousness of the others"

(James Baldwin, "Letter from a region in my mind" in 'The fire next time', pp. 30-31; 110-112)

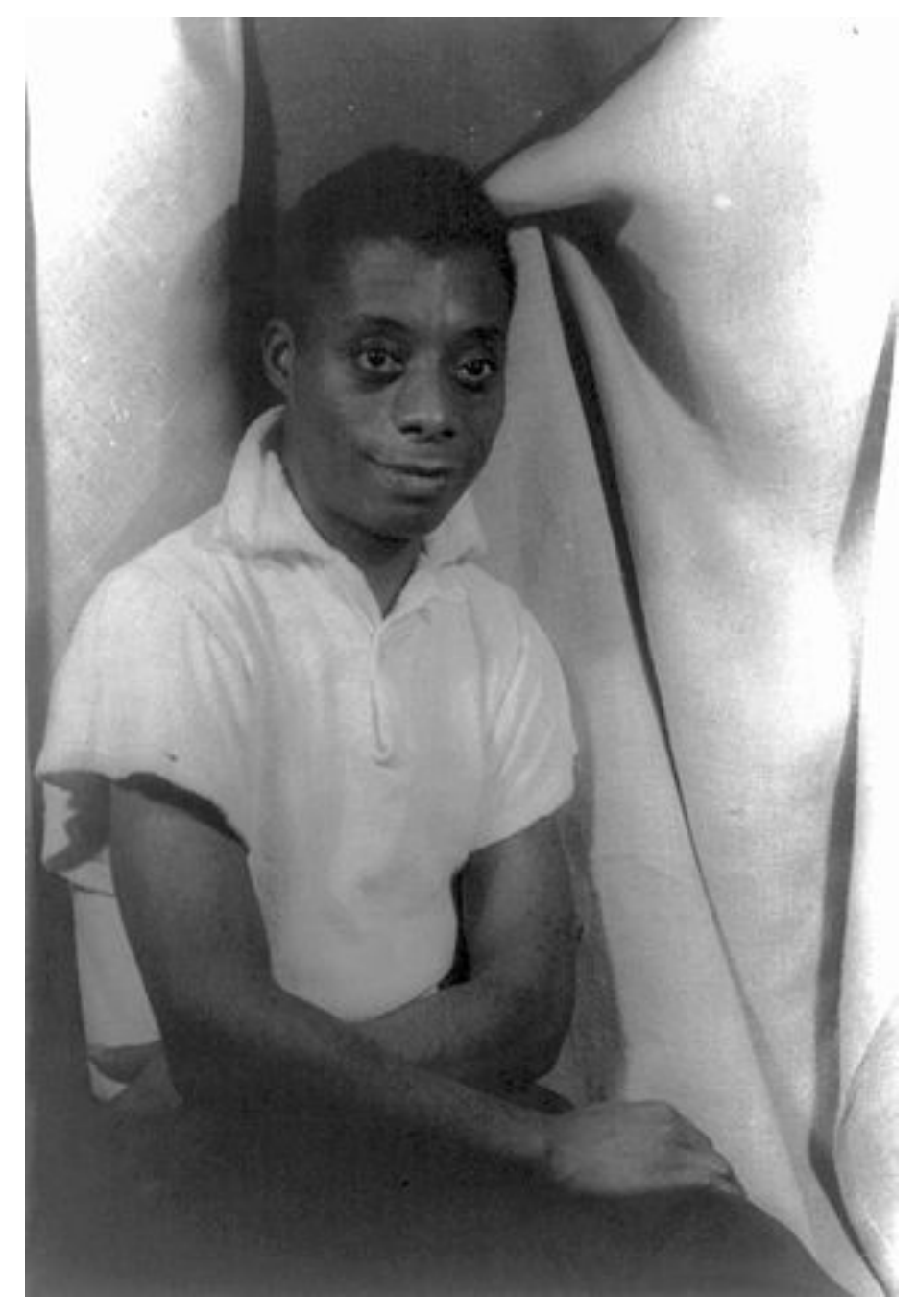

[Ellis was younger than Baldwin, the former from the Chicago ghetto, the other from the New York ghetto - what one of the police officers calls in euphemisms "uptown", I think.] 
Extended 08/02/20; 14/02/20 (“Being a millionaire is difficult...”). 


\section{References}

— Zinn, Howard. 2010. A People's History of the United States, 1942-Present. (Upd. rev. ed.).

- Thompson, E. P.. The Making of the English Working Class.

- Baldwin, James. The Fire Next Time. [Made up of a letter to his nephew, also called James after his uncle, and a lengthy essay published in a magazine $]^{1}$ - Watchmen and Megg, Mogg and Owl [American and other nightmares in color]

${ }^{1}$ I didn't say what happened to him when he was 13 as he was walking to the library, but it's on the same pages. 